\title{
Analgesic, Antiinflammatory and Central Depressor Effects of the Hydroalcoholic Extract and Fractions from Aeolanthus suaveolens
}

\author{
Letícia Veras Costa-Lotufo, ${ }^{*, a}$ David Freitas de Lucena, ${ }^{a}$ Manoel Andrade-Neto, ${ }^{b}$ \\ José Norberto Sousa Bezerra, ${ }^{b}$ Luzia Kalyne Almeida Moreira LeAL, ${ }^{a}$ \\ Francisca Cléa Florência de SousA ${ }^{a}$ and Glauce Socorro de Barros VIANA ${ }^{a}$ \\ ${ }^{a}$ Department of Physiology and Pharmacology, Federal University of Ceará; P.O. Box-3157, 60430-270 Fortaleza, Brazil: \\ and ${ }^{b}$ Department of Organic and Inorganic Chemistry, Federal University of Ceará; P.O. Box 12200, 60021-940, \\ Fortaleza, Brazil. $\quad$ Received December 2, 2003; accepted February 23, 2004
}

This work studied antinociceptive, antiedematogenic and central depressor effects of the hydroalcoholic extract (HAE) from Aeolanthus suaveolens and its fractions: hexane (ASHAE-H), ethyl acetate (ASHAE-A), aqueous (ASHAE-E) and precipitate (ASHAE-PPT) in experimental models in mice. The highest activity in the writhing test was presented by ASHAE-A followed by ASHAE-PPT and ASHAE-E and the lowest by ASHAE-H. In the formalin test the effect was manifested at both phases, although more intensely at the 2 nd phase of the response. In this test, the most active fraction was ASHAE-PPT causing inhibitions of the order of 76 and $90 \%$ of the $2 \mathrm{nd}$ phase of the test at the doses of 10 and $100 \mathrm{mg} / \mathrm{kg}$ i.p., respectively. Naloxone reversed the effects of ASHAE-PPT in both phases of the test, suggesting the participation of the opioid system in the antinociceptive effect. On the other hand, the HAE effect on both phases of the formalin test was only partially reversed by naloxone, suggesting that the extract presents more than one active compound, and at least one, of a polar nature, acting through the opioid system. HAE and ASHAE-PPT presented antiinflammatory activity and were very effective in decreasing the mouse paw edema induced by carrageenan. All fractions significantly decreased locomotor activity in the open field test in mice. However, only the nonpolar fractions presented myorelaxant activity as demonstrated by the rota rod test.

Key words analgesia; antiinflammatory activity; Aeolanthus suaveolens; central effect

Aeolanthus suaveolens, G. Dom known as macassá, is a widespread plant in the Northeastern region of Brazil, and belongs to the Labiatae family. It is commonly used in folk medicine because of its sedative effects. Earlier reports have demonstrated that this species presents the monoterpene, linalool, which is a major component of its essential oil and possibly responsible for the plant anticonvulsant properties. ${ }^{1,2)}$ Linalool inhibited quinolinic acid-induced convulsions, while it increased the latency for $N$-methyl-D-aspartate-induced convulsions. ${ }^{2)}$ In vitro studies demonstrated that linalool displaced $\left[{ }^{3} \mathrm{H}\right]$-glutamate from its receptors, suggesting a negative modulatory action on the central nervous system. ${ }^{1)}$ It was recently reported that linalool also had an inhibitory effect on the acetylcholine $(\mathrm{ACh})$ release and on the channel open time in the mouse neuromuscular junction. ${ }^{3)}$ Preliminary studies with macassá showed that it has an analgesic activity at the doses of 200 and $400 \mathrm{mg} / \mathrm{kg}$. ${ }^{4}$

In the present work, the antinociceptive and antiedematogenic activities of the hydroalcoholic extract from macassá leaves were further investigated together with some of its isolated fractions in an attempt to elucidate their mechanism of action and the participation of the opioid system in the observed effects.

\section{MATERIALS AND METHODS}

Plant Material Leaves $(500 \mathrm{~g})$ from Aeolanthus suaveolens (macassá) were collected at the city of João Pessoa at Paraíba state, Brazil. A voucher specimen (\# 18678) was deposited at the Herbarium Prisco Bezerra (EAC), Department of Biology, Federal University of Ceará, Brazil.

The material was dried before extraction with a $50 \%$ alcohol solution. The hydroalcoholic extract was further parti- tioned with hexane $(1: 4$; repeated four times), and then with ethyl acetate $(1: 4$; repeated four times). The obtained aqueous fraction showed two phases: a soluble one and a precipitate. The phytochemical analyses of macassá extract and its fractions were performed using thin layer chromatography (TLC) and demonstrated the presence of coumarin and alkaloids. The presence of saponins, tannins, steroids and anthraquinone was detected by specific chemical reactions. ${ }^{5}$ The pharmacological analysis was performed using the hydroalcoholic extract (HAE), and its fractions: hexane (ASHAE-H, $2.15 \mathrm{~g}$ ); ethyl acetate (ASHAE-A, $4.78 \mathrm{~g}$ ); aqueous (ASHAE-E, $11.43 \mathrm{~g}$ ) and precipitate (ASHAE-PPT, $9.52 \mathrm{~g})$.

Animals Swiss mice (both sexes, 20-30g) obtained from the central animal house of the Federal University of Ceará, Brazil, were used. Animals were housed in cages with free access to food and water. All animals were kept under a $12 \mathrm{~h}: 12 \mathrm{~h}$ light-dark cycle (lights on at 6:00 a.m.).

Animals were treated with the extract or one of its fractions intraperitoneally $30 \mathrm{~min}$ before the experiments. Controls received vehicle (saline for HAE, ASHAE-PPT and ASHAE-E fractions, control 1 , and 3\% Tween 80 for ASHAE-H and ASHAE-A fractions, control 2) at the same volume as the treated groups $(4 \mathrm{ml} / \mathrm{kg})$.

Analgesic Activity Writhing Test: Female Swiss mice $(20-30 \mathrm{~g})$ were used according to the method described by Koster et al. ${ }^{6}$ ) The total number of writhings following intraperitoneal administration of $10 \mathrm{ml} / \mathrm{kg}$ of $0.6 \%$ acetic acid was recorded over a period of $20 \mathrm{~min}$, starting $10 \mathrm{~min}$ after the acetic acid injection. Animals received HAE (5 or $50 \mathrm{mg} / \mathrm{kg}$, i.p.) or fractions ( 5 or $50 \mathrm{mg} / \mathrm{kg}$, i.p.) $30 \mathrm{~min}$ before the acetic acid administration. Control animals received vehicle. 
Formalin Test: Formalin-induced paw-licking was determined essentially as described by Murray et al. ${ }^{7)}$ Female Swiss mice $(20-30 \mathrm{~g})$ were injected in the subplantar area of the right hind paw with formalin $(1 \%, 20 \mu \mathrm{l})$. The duration of the paw licking, an index of nociception, was measured from $0-5 \mathrm{~min}$ (early phase) and from 20-25 min (late phase) after the formalin administration. Animals were administered with HAE (10 or $100 \mathrm{mg} / \mathrm{kg}$, i.p.) or fractions (10 or $100 \mathrm{mg} / \mathrm{kg}$, i.p.), $30 \mathrm{~min}$ before the intraplantar injection of formalin. Morphine $(5 \mathrm{mg} / \mathrm{kg}$, s.c.) pretreated animals were included in the study, as a standard, for comparison. In a separate experiment, the pretreatment effect of naloxone $(2 \mathrm{mg} / \mathrm{kg}$, s.c.) was analyzed in order to verify the possible antinociception mechanism and the involvement of the opioid system.

Antiinflammatory Activity Paw edema was induced in the hind paw of mice by the subplantar injection of $1 \%(\mathrm{w} / \mathrm{v})$ lambda carrageenan. After the injection, the paw volume $(\mu 1)$ was determined with a plethysmometer (Ugo Basile, Italy), as described by Winter et al., ${ }^{8)}$ at 1, 2, 3, 4 and $24 \mathrm{~h}$. The edema was reported as the difference between the final and the initial paw volume. Animals received HAE or fractions at doses ranging from 5 to $200 \mathrm{mg} / \mathrm{kg}$, i.p., $30 \mathrm{~min}$ before the carrageenan administration.

Central Depressor Effects Open Field Test: Mice (male, 20-30 g) were observed for exploratory activity by placing them in the centre of an open field arena $(40 \mathrm{~cm}$ diameter) as described by Ascher. ${ }^{9}$ The observed parameters were: number of squares crossed with the four paws and numbers of grooming and rearing during a period of observation of $5 \mathrm{~min}$.

Rota Rod: Each mouse was placed with its four paws on a $2.5 \mathrm{~cm}$ diameter bar $25 \mathrm{~cm}$ above the floor, which was turning at $12 \mathrm{rpm}$. For each animal, the number of falls (up to three) and the time spent on the bar for 1 min were registered. ${ }^{10)}$

Statistical Analysis Data are presented as mean \pm S.E.M. of $n$ experiments and analyzed with analysis of variance (ANOVA) followed by Student Newman-Keuls. The significance level was $5 \%$.

\section{RESULTS}

Table 1 shows the effects of HAE and isolated fractions on the writhing test in mice. Although significant inhibitions of the acetic acid-induced abdominal contractions were observed with HAE and all fractions tested, the most active one was ASHAE-A, while the least active was ASHAE-H. In the first case (ASHAE-A), 71\% inhibition was already observed with the dose of $5 \mathrm{mg} / \mathrm{kg}$ i.p., while the highest dose $(50 \mathrm{mg} / \mathrm{kg}$, i.p.) caused $96 \%$ inhibition. With the same doses, ASHAE-H fraction produced inhibitions on the order of 28 and $68 \%$, respectively. Intermediate values were seen with the other two fractions (ASHAE-E and ASHAE-PPT).

In the formalin test (Table 2), HAE $(100 \mathrm{mg} / \mathrm{kg})$ significantly inhibited the response at both phases, similar to morphine $(5 \mathrm{mg} / \mathrm{kg}$, s.c., Fig. 1). The HAE inhibition was not significant at the lowest dose $(10 \mathrm{mg} / \mathrm{kg})$. The vehicle used for ASHAE-H and ASHAE-A alone (control 2) also significantly inhibited the 2nd phase of the test, although to a less extent. Both nonpolar fractions inhibited the paw licking response in the $1 \mathrm{st}$ phase at the dose of $100 \mathrm{mg} / \mathrm{kg}$. Among the
Table 1. Effect of the Hydroalcoholic Extract (HAE) from Aeolanthus suaveolens and Its Fractions (ASHAE-H; ASHAE-A; ASHAE-E; ASHAE$\mathrm{PPT})$ on the Acetic Acid-Induced Nociception in Mice

\begin{tabular}{lcccc}
\hline \hline Group & $\begin{array}{c}\text { Dose } \\
(\mathrm{mg} / \mathrm{kg})\end{array}$ & $\begin{array}{c}\text { Writhing } \\
\text { movements }\end{array}$ & $n$ & $\begin{array}{c}\text { \% of } \\
\text { Inhibition }\end{array}$ \\
\hline Control 1 & - & $42.4 \pm 1.3$ & 16 & - \\
HAE & 5 & $23.6 \pm 5.2^{a)}$ & 10 & 44.3 \\
ASHAE-E & 50 & $3.2 \pm 1.2^{a)}$ & 14 & 92.4 \\
ASHAE-PPT & 5 & $17.3 \pm 1.8^{a)}$ & 7 & 59.1 \\
Control 2 & 50 & $2.4 \pm 1.0^{a)}$ & 8 & 94.3 \\
ASHAE-H & 5 & $16.5 \pm 2.6^{a)}$ & 8 & 61.1 \\
ASHAE-A & 5 & $4.2 \pm 1.1^{a)}$ & 8 & 90.1 \\
& 50 & $35.3 \pm 1.5$ & 8 & - \\
& 5 & $25.4 \pm 2.4^{a)}$ & 8 & 28.4 \\
& 50 & $11.3 \pm 2.5^{a)}$ & 8 & 68.0 \\
& & $10.4 \pm 1.9^{a, b)}$ & 8 & 70.5 \\
& & $1.4 \pm 0.6^{a)}$ & 8 & 96.0
\end{tabular}

Animals were treated with HAE or fractions, $30 \mathrm{~min}$ before the acetic acid injection. Results represent mean \pm S.E.M. of the number of writhings recorded for $20 \mathrm{~min}$, starting 10 min after acetic acid administration. a) $p<0.05$ as compared to the respective control and $b$ ) $p<0.05$ as compared to HAE at the same dose using ANOVA followed by Student Newman Keuls as the post hoc test. Control $1=$ saline used in case of HAE, ASHAE-E, ASHAE-PPT. Control $2=3 \%$ Tween 80 , vehicle used for the suspension of ASHAE-H and ASHAE-A.

Table 2. Effect of the Hydroalcoholic Extract (HAE) from Aeolanthus suaveolens and Its Fractions (ASHAE-H; ASHAE-A; ASHAE-E; ASHAEPPT) on the Formalin-Induced Nociception in Mice

\begin{tabular}{|c|c|c|c|c|c|c|}
\hline \multirow[b]{2}{*}{ Group } & \multirow{2}{*}{$\begin{array}{c}\text { Dose } \\
(\mathrm{mg} / \mathrm{kg})\end{array}$} & \multicolumn{2}{|c|}{ Licking time (s) } & \multirow[b]{2}{*}{$n$} & \multicolumn{2}{|c|}{$\%$ of Inhibition } \\
\hline & & $\begin{array}{c}\text { 1st } \\
\text { phase }\end{array}$ & $\begin{array}{c}\text { 2nd } \\
\text { phase }\end{array}$ & & $\begin{array}{c}\text { 1st } \\
\text { phase }\end{array}$ & $\begin{array}{c}\text { 2nd } \\
\text { phase }\end{array}$ \\
\hline Control 1 & - & $62.8 \pm 2.8$ & $30.3 \pm 4.3$ & 11 & - & - \\
\hline \multirow[t]{2}{*}{ HAE } & 10 & $57.3 \pm 6.7$ & $26.4 \pm 3.4$ & 12 & 7.8 & 12.8 \\
\hline & 100 & $37.4 \pm 2.7^{a)}$ & $\left.6.6 \pm 1.9^{a}\right)$ & 10 & 40.3 & 78.2 \\
\hline \multirow[t]{2}{*}{ ASHAE-E } & 10 & $54.3 \pm 6.7$ & $29.3 \pm 8.3$ & 6 & 13.5 & 3.4 \\
\hline & 100 & $31.0 \pm 3.1^{a)}$ & $7.7 \pm 4.1^{a)}$ & 6 & 50.3 & 74.6 \\
\hline \multirow[t]{2}{*}{ ASHAE-PPT } & 10 & $55.5 \pm 5.7$ & $7.3 \pm 3.3^{a, b)}$ & 6 & 11.6 & 76.0 \\
\hline & 100 & $\left.23.3 \pm 3.0^{a}\right)$ & $3.2 \pm 1.4^{a)}$ & 12 & 62.8 & 89.4 \\
\hline Control 2 & - & $62.2 \pm 3.0$ & $16.6 \pm 4.3^{a)}$ & 12 & - & 45.2 \\
\hline \multirow[t]{2}{*}{ ASHAE-H } & 10 & $48.8 \pm 5.3$ & $3.0 \pm 1.6^{b)}$ & 6 & 21.5 & 82.0 \\
\hline & 100 & $36.7 \pm 8.9^{a)}$ & $4.3 \pm 4.3$ & 6 & 41.0 & 74.1 \\
\hline \multirow[t]{2}{*}{ ASHAE-A } & 10 & $39.5 \pm 3.4$ & $3.8 \pm 3.5^{b)}$ & 6 & 36.5 & 77.1 \\
\hline & 100 & $\left.36.5 \pm 5.4^{a}\right)$ & $10.2 \pm 5.7$ & 6 & 41.3 & 38.5 \\
\hline
\end{tabular}

Animals were treated with HAE or fractions, intraperitoneally, 30 min before the intraplantar injection of $1 \%$ formalin. Results represent mean \pm S.E.M. of the licking time. a) $p<0.05$ as compared to the respective control and $b$ ) $p<0.05$ as compared to HAE at the same dose using ANOVA followed by Student Newman Keuls as the post hoc test. Control $1=$ saline, used in case of HAE, ASHAE-E, ASHAE-PPT. Control $2=3 \%$ Tween 80 , vehicle used for suspension of ASHAE-H and ASHAE-A.

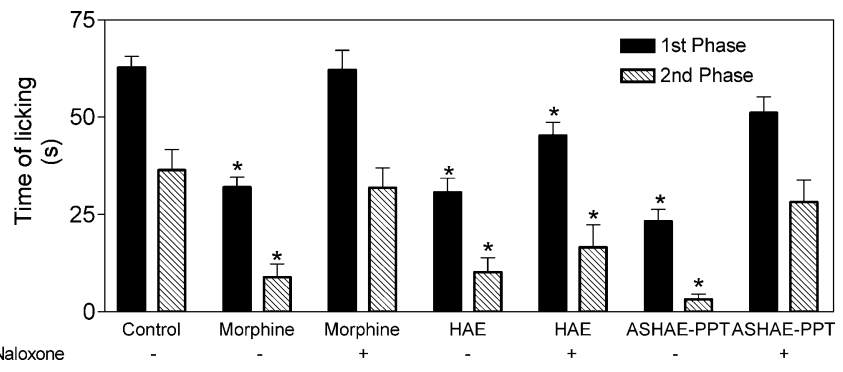

Fig. 1. Effects of the Hydroalcoholic Extract from Aeolanthus suaveolens (HAE) and Its Fraction ASHAE-PPT ( $100 \mathrm{mg} / \mathrm{kg}$, i.p.) on the Formalin-Induced Nociception in Mice

Animals were treated with HAE or ASHAE-PPT, $30 \mathrm{~min}$ before the intraplantar injection of $1 \%$ formalin. Results represent mean \pm S.E.M. of the licking time from at least 12 animals. Morphine $(5 \mathrm{mg} / \mathrm{kg}$, s.c.) was used as positive control. Experiments were also performed in the presence of naloxone $(2 \mathrm{mg} / \mathrm{kg}, \mathrm{s.c}) . * p<0.05$ as compared to control (ANOVA followed by Student Newman Keuls). 
A

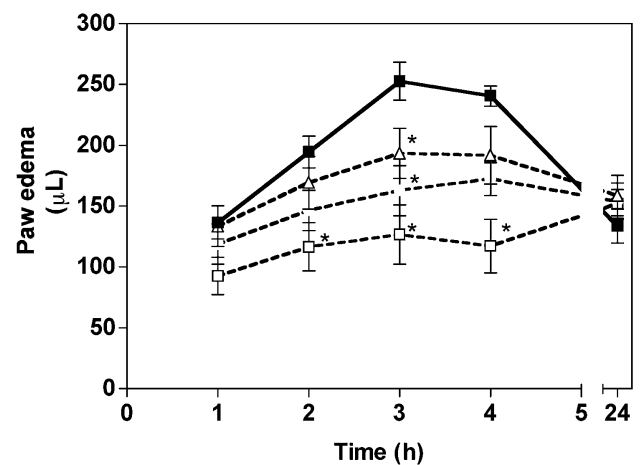

B

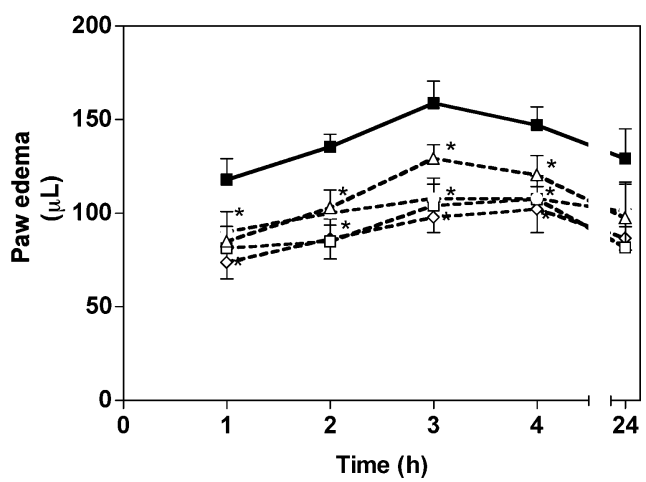

Fig. 2. Effects of the Hydroalcoholic Extract (HAE) from Aeolanthus suaveolens (A) and Its Fraction ASHAE-PPT (B) in Carrageenan-Induced Mouse Paw Edema

Each point represents the mean \pm S.E.M. for $n$ animals. (A) HAE: $\mathbf{0}$, Control $(n=15) ; \triangle, 50 \mathrm{mg} / \mathrm{kg}(n=17) ; \bigcirc, 100 \mathrm{mg} / \mathrm{kg}(n=17) ; \square, 200 \mathrm{mg} / \mathrm{kg} \quad(n=17)$. (B) ASHAE-PPT: $\square$, Control $(n=17) ; \triangle, 5 \mathrm{mg} / \mathrm{kg}(n=12) ; \bigcirc 10 \mathrm{mg} / \mathrm{kg}(n=12) ; \square$, $50 \mathrm{mg} / \mathrm{kg}(n=12) ; \diamond, 100 \mathrm{mg} / \mathrm{kg}(n=12) . * p<0.05$ as compared to control (ANOVA followed by Student Newman Keuls).

polar fractions (ASHAE-E and ASHAE-PPT), the most active was ASHAE-PPT, which produced a significant inhibition of the 2 nd phase $(76 \%, p<0.05)$ even at the smallest dose $(10 \mathrm{mg} / \mathrm{kg})$. Inhibitions of the 1 st phase were observed with both polar fractions, ASHAE-E and ASHAE-PPT, at the dose of $100 \mathrm{mg} / \mathrm{kg}$ (50.3 and $62.8 \%$, respectively). Naloxone completely blocked the antinociceptive effect of morphine and ASHAE-PPT, but it only partially modified the HAE effect.

HAE $(50,100$ and $200 \mathrm{mg} / \mathrm{kg}$ ) was very effective in causing inhibition of the paw volume in the carrageenan-induced paw edema in mice (Fig. 2A). The extract showed a significant effect even at the smallest dose $(50 \mathrm{mg} / \mathrm{kg})$, which inhibited paw edema by $23 \%$ at the 3 rd hour after carrageenan administration. Higher inhibitions were detected with the doses of 100 and $200 \mathrm{mg} / \mathrm{kg}$ (36 and 50\%, respectively) at the same period of time. As a matter of fact, the effect, which was time-dependent, lasted for at least $4 \mathrm{~h}$ with the two highest doses. ASHAE-PPT also caused a significant reduction in the paw edema induced by carrageenan $(19,32,34$ and $38 \%$, respectively) at the doses of 5, 10, 50 and $100 \mathrm{mg} / \mathrm{kg}$ (Fig. 2B).

Results from the open field test in mice are presented in Table 3. All fractions significantly inhibited crossing as compared to the saline-treated group (control 1) or to the vehicletreated group (control 2). In addition, except for fractions ASHAE-H and ASHAE-E, which did not alter rearing or grooming, all other fractions caused significant inhibitions of
Table 3. Effect of the Hydroalcoholic Extract (HAE) from Aeolanthus suaveolens and Its Fractions (ASHAE-H; ASHAE-A; ASHAE-E; ASHAEPPT) in the Open Field Test in Mice

\begin{tabular}{lccccr}
\hline \hline & $\begin{array}{c}\text { Dose } \\
(\mathrm{mg} / \mathrm{kg})\end{array}$ & $\begin{array}{c}\text { Number of } \\
\text { squares crossed }\end{array}$ & Rearing & Grooming & $n$ \\
\hline Control & - & $69.5 \pm 2.5$ & $11.4 \pm 1.1$ & $4.2 \pm 0.5$ & 20 \\
HAE & 50 & $53.0 \pm 5.9^{a)}$ & $4.9 \pm 2.8^{a)}$ & $1.6 \pm 0.7^{a)}$ & 12 \\
& 100 & $36.8 \pm 5.0^{a)}$ & $1.6 \pm 1.2^{a)}$ & $0.2 \pm 0.1^{a)}$ & 8 \\
ASHAE-E & 10 & $51.8 \pm 3.3^{a)}$ & $7.0 \pm 1.6$ & $1.8 \pm 0.4^{a)}$ & 5 \\
& 100 & $30.8 \pm 4.0^{a)}$ & $10.2 \pm 2.4$ & $2.4 \pm 0.5$ & 5 \\
ASHAE-PPT & 10 & $37.6 \pm 5.8^{a)}$ & $3.0 \pm 1.6^{a)}$ & $1.6 \pm 0.5^{a)}$ & 5 \\
& 100 & $37.9 \pm 7.6^{a)}$ & $0.8 \pm 0.6^{a)}$ & $0.6 \pm 0.4^{a)}$ & 5 \\
Control 2 & - & $68.4 \pm 3.2$ & $11.5 \pm 1.0$ & $4.2 \pm 0.4$ & 10 \\
ASHAE-H & 10 & $50.2 \pm 6.0^{a)}$ & $14.2 \pm 2.2$ & $2.8 \pm 0.6$ & 5 \\
& 100 & $54.4 \pm 2.9^{a)}$ & $9.6 \pm 2.7$ & $3.0 \pm 1.0$ & 5 \\
ASHAE-A & 10 & $76.2 \pm 5.8$ & $5.6 \pm 2.6$ & $1.2 \pm 0.5^{a)}$ & 5 \\
& 100 & $35.2 \pm 5.5^{a)}$ & $0.8 \pm 0.4^{a)}$ & $0.6 \pm 0.4^{a)}$ & 5
\end{tabular}

Animals were treated with HAE or fractions, intraperitoneally, $30 \mathrm{~min}$ before test. Results represent mean \pm S.E.M. a) $p<0.05$ compared to the respective control using ANOVA followed by Student Newman Keuls as the post hoc test. Control 1=saline, used in case of HAE, ASHAE-E, ASHAE-PPT. Control 2=3\% Tween 80, vehicle used for suspension of ASHAE-H and ASHAE-A.

Table 4. Effect of the Hydroalcoholic Extract (HAE) from Aeolanthus suaveolens and Its Fractions (ASHAE-H; ASHAE-A; ASHAE-E; ASHAEPPT) on the Rota Rod Test in Mice

\begin{tabular}{lrrrr}
\hline \hline \multicolumn{1}{c}{ Group } & $\begin{array}{c}\text { Dose } \\
(\mathrm{mg} / \mathrm{kg})\end{array}$ & $n$ & $\begin{array}{c}\text { Number of } \\
\text { falls }\end{array}$ & $\begin{array}{c}\text { Time of } \\
\text { permanence (s) }\end{array}$ \\
\hline Control & - & 20 & $1.0 \pm 0.3$ & $51.5 \pm 3.4$ \\
HAE & 50 & 14 & $2.1 \pm 0.3$ & $40.6 \pm 5.0$ \\
& 100 & 10 & $1.7 \pm 0.4$ & $40.1 \pm 6.7$ \\
ASHAE-E & 10 & 5 & $1.0 \pm 0.4$ & $60.0 \pm 0.0$ \\
ASHAE-PPT & 100 & 5 & $0.8 \pm 0.4$ & $57.2 \pm 1.3$ \\
& 10 & 5 & $2.4 \pm 0.4$ & $45.0 \pm 6.3$ \\
Control 2 & - & 10 & $2.4 \pm 0.4$ & $38.2 \pm 6.0$ \\
ASHAE-H & 10 & & $0.7 \pm 0.3$ & $57.6 \pm 1.0$ \\
& 100 & 5 & $2.8 \pm 0.2^{a)}$ & $37.2 \pm 7.8^{a)}$ \\
ASHAE-A & 10 & & $2.6 \pm 0.2^{a)}$ & $31.0 \pm 9.1^{a)}$ \\
& 100 & 5 & $1.4 \pm 0.5$ & $52.4 \pm 7.6$ \\
& & 5 & $2.4 \pm 0.6^{a)}$ & $30.8 \pm 8.2^{a)}$ \\
\hline
\end{tabular}

Animals received HAE or fractions, intraperitoneally, $30 \mathrm{~min}$ before the test. Results represent mean \pm S.E.M. a) $p<0.05$ compared to the respective control using ANOVA followed by Student Newman Keuls as the post hoc test. Control $1=$ saline, used in case of HAE, ASHAE-E, ASHAE-PPT. Control 2=3\% Tween 80, vehicle used for suspension of ASHAE-H and ASHAE-A.

both parameters. Furthermore, greater effects were observed with the more polar fractions, especially ASHAE-PPT which significantly decreased by $46 \%$ the locomotor activity, even at the dose of $10 \mathrm{mg} / \mathrm{kg}$. In the rota rod test (Table 4), HAE and its polar fractions (ASHAE-E and ASHAE-PPT) caused no significant effect on the time of permanence on the bar or on the number of falls compared to control 1. On the other hand, ASHAE-H and ASHAE-A significantly reduced the time of permanence on the bar and increased the number of falls at the concentration of $100 \mathrm{mg} / \mathrm{kg}$. At the smallest dose $(10 \mathrm{mg} / \mathrm{kg})$ ASHAE-H also decreased the time of permanence on the bar and increased the number of falls as compared to the vehicle-treated group (control 2).

The phytochemical study of the HAE showed that this extract lacks coumarin, steroids and anthraquinone, but has alkaloids, saponins and tannins as components. The same phytochemical profile was observed with ASHAE-PPT (data not shown). 


\section{DISCUSSION}

In this work we showed that the HAE from A. suaveolens and its fractions present a potent antinociceptive effect as demonstrated by the writhing and formalin tests in mice. The effects were dose-dependent and in the writhing test (except for ASHAE-H), they were observed at the smallest dose $(5 \mathrm{mg} / \mathrm{kg})$. The highest activity was shown by ASHAE-A followed closely by ASHAE-PPT and ASHAE-E and the lowest by ASHAE-H.

In the formalin test the effect was manifested in both phases, although more intensely in the 2 nd phase of the response. In this test, the most active fraction was ASHAEPPT causing inhibitions of the order of 76 and $90 \%$ of the 2nd phase of the test at the doses of 10 and $100 \mathrm{mg} / \mathrm{kg}$, respectively. The formalin test is considered a valid model for clinical pain. ${ }^{11)}$ The first phase of the behavioral response is thought to be produced by direct activation of nociceptive neurons, while the second phase corresponds to inflammatory pain, and thus involves the release of mediators of the inflammatory process. ${ }^{12,13)}$ We also showed that naloxone reversed the effects of the ASHAE-PPT in both phases of the test, suggesting the participation of the opioid system on its antinociceptive effect. On the other hand, the HAE effect on both phases of the formalin test was only partially reversed by naloxone, suggesting that the extract probably contains more than one active compound, and at least one, of a polar nature, acts through the opioid system.

Furthermore, HAE and ASHAE-PPT were also tested on the carrageenan-induced paw edema in order to study their possible antiinflammatory action. HAE and its fraction (ASHAE-PPT) were all very effective in decreasing rat paw volume. As a matter of fact, HAE at the doses of 50, 100 and $200 \mathrm{mg} / \mathrm{kg}$ decreased 23, 36 and 50\%, respectively, the paw volume at the 3rd hour after administration of carrageenan, while ASHAE-PPT induced a significant and dose-dependent inhibition of the edema even at the dose of $5 \mathrm{mg} / \mathrm{kg}$. The inhibition observed with ASHAE-PPT at the dose of $10 \mathrm{mg} / \mathrm{kg}$ was the same as that observed with HAE at a dose 10 times higher $(100 \mathrm{mg} / \mathrm{kg})$. The edema induced by carrageenan presents an acute phase lasting up to $24 \mathrm{~h}$ and a 2 nd phase which starts after $24 \mathrm{~h}$ and lasts at least $72 \mathrm{~h}$ after its administration. ${ }^{14)}$ The edema involves the release of several mediators such as 5-HT, histamine, bradikynin and prostaglandins ${ }^{15}$ ) and active compounds may act on one or on several steps of the inflammatory process.

All fractions significantly decreased locomotor activity as demonstrated by the open field test in mice and their effects were very similar. Our results possibly explain the plant sedative effect and also justify its popular use as a tranquil- izer. However, as far as rearing and grooming are concerned, ASFHAE-A and ASFHAE-PPT were very active significantly decreasing these two parameters as compared to controls. HAE and its polar fractions (ASHAE-E and ASHAEPPT) did not cause any significant myorelaxant activity as demonstrated by the rota rod test. Although the nonpolar fractions (ASHAE-H and ASHAE-A) caused an effect at a higher dose, no significant effect was observed with the lower dose in the ASHAE-A treated group. Probably, the decrease in locomotor activity observed in the open field test with these fractions is in part due to motor uncoordination.

In conclusion, we showed a potent analgesic and antiinflammatory activities in the hydroalcoholic extract from $A$. suaveolens and in ASHAE-PPT, one of its fractions. At least part of the analgesic effect is related to the opioid system. Furthermore, a great decrease of the locomotor activity with no myorelaxant effect was also observed with ASHAE-PPT. All together, these data indicate that polar components present in A. suaveolens are responsible for some of the effects observed in the present work. However, we cannot exclude the participation of other bioactive components.

\section{REFERENCES}

1) Elisabetsky E., Marschner J., Souza D. O., Neurochem. Res., 20, 461465 (1995).

2) Elisabetsky E., Brum L. F., Souza D. O., Phytomedicine, 6, 107-113 (1999).

3) Re L., Barocci S., Sonnino S., Mencarelli A., Vivani C., Paolucci G., Scarpantonio A., Rinaldi L., Mosca E., Pharmacol. Res., 42, 177182 (2000).

4) Bezerra A. E. M., Porto A. P. M., Cavalcante M. C., Sousa F. C. F., De Bruin V. M. S., Resumo no. 12.191 apresentado na "XIV Reunião Anual da Federação de Sociedades de Biologia Experimental," FESBE, São Paulo, Brazil, 1999, p. 392.

5) Costa A. F., "Farmacognosia," Vol. 1-2, 2nd ed. Fundação Calouste Gulbenkain, Lisbon, 1977.

6) Koster R., Anderson M., de Beer E. J., Fed. Proc., 18, 412-417 (1959).

7) Murray C. W., Porreca F., Cowan A., J. Pharmacol. Meth., 20, 175186 (1988).

8) Winter C. A., Risely E. A., Nuss G. W., Proc. Soc. Exp. Biol. Med., 111, 544-547 (1962).

9) Ascher J., Animal Behavior, 21, 205-235 (1973).

10) Dunham N. W., Miya T. S., J. American Pharmaceut. Assoc., 46, 208 (1957).

11) Weyers W., Brodbeck B. W., Pharm. Unserer Zeit., 19, 82-86 (1989).

12) Hunskaar S., Hole K., Pain, 30, 103-114 (1987).

13) Hong Y., Abbot F. V., Eur. J. Pharmacol., 277, $21-28$ (1995).

14) Henriques M. G. M. O., Silva P. M. R., Martins M. A., Flores C. A., Cunha F. Q., Assreuy-Filho J., Cordeiro R. S. B., Brazilian J. Med. Biol. Res., 20, 243-249 (1987).

15) Di Rosa M., Giroud J. P., Willoughby D. A., J. Pathology, 104, 15-29 (1971). 